\title{
Problem of Social Identity in the Globalized World
}

\author{
Irina A. Kardonova and Vladimir I. Kuibar* \\ Irkutsk State University \\ 3 Karl Marx Str., Irkutsk, 664003, Russia
}

Received 24.02.2018, received in revised form 03.04.2018, accepted 25.04.2018

\begin{abstract}
Article is devoted to a problem of social identity in the globalized world. It is characteristic that "threats" of identity which face during globalization processes are represented more real and obvious while "prizes" remain more speculative. Advantages which are born with itself in respect of identification processes by globalization are usually described in connection with a phenomenon of liberty of choice of such identity. The categories of evidence "obvious" to "globalisers" act as a universal criterion with which they approach assessment of all phenomena and social practice accompanying globalization in general. It is natural that such approach has to encounter the known resistance - the symbolical violence committed at the global level is resisted both by symbolical barriers at the local levels, and the antiglobalistic movement, itself gaining global character.
\end{abstract}

Keywords: identification, globalization processes, symbols.

DOI: 10.17516/1997-1370-0265.

Research area: culturology.

\section{Introduction}

The social identity in the context of globalization processes draws the increasing attention of researchers, and is analyzed as in the context of relevant and potential prizes, and threats. In general, as is well-known, the anthropological reflection, or identification, is defined how all other identifications (sexual, racial, ethnocultural, civil, class, professional), by the negative and positive principle that is caused, respectively, by existence of opposite and identical individuals. In opposition of two subjectivity their mutual symbolical ranks are formed on the basis of character of the relations which they among themselves entered. "The endured relations, - Martin Buber writes, - an essence of realization congenital You in that You which is found through a meeting; what met You can be comprehended as forthcoming is apprehended in exclusiveness and, at last, the fact that to it the main word can be turned, is implanted in a priori relations" (Buber, 1995). In these relations affective, "expressional" (Parsons), the party plays an extremely important role in the course of mutual perception, and the intensity of experience defines both an arsenal of the symbolizing means, and degree of figurative saturation, in other words - the width and depth of a palette of the symbols caused in the person by the "forthcoming" personality.

(C) Siberian Federal University. All rights reserved

* Corresponding author E-mail address: naukaitfk@mail.ru 


\section{Point of view}

The group with which the individual identifies himself is always a phenomenon of a symbolical order, the carrier and a mediator of meanings, identity and values of the individuals included in it. In this regard, Anthony Coen selects two most basic characteristics of this social unit: "members of human group (a) have something the general among themselves what (would) distinguish in their significant way from members of other group. "Community", thus, assumes at the same time similarity and difference. As the embodiment of these characteristics group borders act" (Cohen, 2000).

The symbolical universum of the personality is formed and supported due to positive and negative identification where the first is identification with similar, the second finding of through understanding of existence of the vis-a-vis. The fact of awareness of own not identity with someone has character of the known stress. To weaken these experiences and to give them positive orientation, are called prestige, or - pathos of group - the stored and cultivated symbolical arch approving its superiority over all other. The complex of symbols of group is designed to regulate its state, and is implemented through daily practicians, or as Zdislav Mach prefers to formulate, rituals. "All groups express the identity through rituals, and provide a social order and due behavior of the members. If between groups there is a conflict, rituals express differences between them, and divide the social world into two resisting orders - our and their, positive and negative. Thus, both social control and social change, - according to Mach, - are functions of a ritual, and, in effect, two aspects of the same process of symbolical representation and creation of identity" (Mach, 1993). Positive assessment of own group and negative - the stranger is nearly the patrimonial characteristic of any group symbolical complex. "Symbolical borders are created for division of the world into "ours" and "their" domains, - according to Mach, - the Social space will be organized according to this division defining as well patterns of interaction between various groups. These relations consist, in addition, in further process of identification, consolidation of the corresponding models of identity" (Cohen, 2000).

It is characteristic, in this regard, that "threats" of identity which it faces during globalization processes are represented more real and obvious while "prizes" remain more speculative. Advantages which are born with itself in respect of identification processes by globalization are usually described in connection with a phenomenon of liberty of choice of such identity. "Distinctive feature of symbolical domination, - Bourdieu says, - what it inspires in those who submit to it, the representation which is throwing down a challenge to a habitual dichotomy of freedom and restriction" (Bourdieu, 1991) is. This observation as well as possible corresponds to current situation with assessment of a problem of identity and freedom in the globalized world. Anthony Giddens, for example, claims that "the tradition and custom more and more weaken the impact on our lives", and it is positive, according to Giddens, process as it "provides to the person the level of personal liberty unprecedented before" (Giddens, 2000). The famous writer and the publicist M.V. Llosa when says that "globalization has to be welcomed only as incredibly expands the horizons of individual freedom" (Llosa, 2001) echoes this approach. The similar opinion is expressed also by Peter Berger when he writes that "at the cultural level there was a serious call of pluralism: destruction of self-evident traditions and emergence of a possibility of the choice among beliefs, values and vital styles. It is represented proved to tell that this process leads to increase in both individual, and collective freedom. It 
is unlikely the one who appreciates freedom will blame this development, despite its price" (Berger, 2002). In turn, UNESCO in the Report on the World Culture of 2000 proclaims that "the mankind has to expand the concept about cultural heritage due to inclusion in it of non-material phenomena, such as tradition and custom, along with great monuments and nature sanctuaries", expressing, however, at the same time concern on the fact that "the cultural identity and expression testing various calls from globalization processes can lead to denial of a variety, therefore, culture can quickly be connected with the conflict" (World Culture Report, 2000).

Actually, on the potential symbolical and direct conflict the argument of those researchers who see threat of social identity from globalization processes is also constructed. Such domestic thinker as A.S. Panarin notes that during globalization society, actually, is disarmed in the face of the corporations using for legitimation and upclassing of the mercenary purposes of clothes of the doctrine of postmodernism. At the level of intellectuals it is disarmed due to redirection of cogitative activity towards apologetics of bad relativity and absolute mosaicity - when "anything there can be from everything, anything”, search of the truth becomes occupation, at least, senseless. At the level of inhabitants society loses an opportunity to resistance due to virtualization of all social communications and destruction of the metanarrativ branded by postmodernism - identities, ideologies, nationality. There are, according to Panarin, so-called deserters of society, "the burden of social discipline and a debt refusing to bear in all its manifestations. These deserters in own way cooperate in business of a deconstruction of the national state, army, the industry, that is help globalists to eliminate barriers on the way of globalization. They - too individualists, but their individualism, unlike individualism of privatizator, has the infantile and helpless, self-disarming character" (Panarin, 2003). Postmodernism, - Panarin claims, - gave to private-ownership, individualistic motives of old bourgeois type "a new form of individualistic reconquest of socially irresponsible "freedom" avoiding any debt, any norms, everything which is smelling slightly of "collective sacrifice". So, the mass "postmodern" type of a decadent warehouse embodying social lack of will and tendency to any desertion (from deserters of the industry to deserters of family, school and army)" (Panarin, 2003) became more or less involuntary colleague and the fellow traveler of new privatizator. It is characteristic, according to the Russian scientist and the fact that in a limit the mechanism of a deconstruction indicates prospect when on one pole the citizens of a superstate feeling act and is material, and symbolically propertied, on another - the inhabitants of the periphery bared to the level of primitive "body". And at first inspire in these inhabitants that came it is time to be exempted from freight of all of "traditional culture", that is to become culturally uncharged body, and then they which are culturally disarmed and therefore completely "plastic" in others hands will be bared also in purely physical, material relation.

At the same time, the modern German researcher Hejko Schrader expresses opinion that the national identity is lost today in general everywhere, including "the states of prosperity", also mentioning, however, a role in this process of postmodern deconstructivism: "The decline of great ideologies during a collapse of the centralized economies promotes loss of identity". Besides, according to Schrader, - in many countries the national identity is called into question for other reason: "the national states which arose during the post-colonial period contrary to the national states of the old world, especially in the countries with deep traditions of civil society, such as France or England, are characterized by gradual disintegration of national and ethnic identities. 
Frontiers are rather political, than ethnic borders, and national identities, as well as ethnicity, are designs which can compete with each other" (Schrader, 1998).

To opinions on postmodern legitimation of corporate interests in globalization, generally, there corresponds also approach of such American researchers as Joshua Yates and James Hunter who in the work devoted to a problem of motivations and attitudes of "globalisers" (the leading corporations, religious, cultural, and other public organizations of the international level) say about what "globalisers" use specific vocabuliar based on structure of the divided experience and the general prospects, including the concepts obtained from the fields of social science, human rights, the market and multiculturalism. "This vocabuliar provides conditions thanks to which the power of global instructions is created, and its private tool purposes are legitimized. ... If the epistemological power of global elite is founded on language of social science, then the moral power leans on language of the universal individual rights and requirements" (Hunter, 2002). That is, it is talked about aspiration of global elite "to give the status of generality" (Marx) to own values and views that has to provide symbolical violence with necessary "not persistence" and legitimacy. The categories of evidence "obvious" to "globalisers" act as a universal criterion with which they approach assessment of all phenomena and social practice accompanying globalization in general. It is natural that such approach has to encounter the known resistance - the symbolical violence committed at the global level is resisted both by symbolical barriers at the local levels, and the antiglobalistic movement, itself gaining global character.

\section{Example}

Manuel Castells proving that "in information society the power becomes entered at the fundamental level in cultural codes by means of which people and institutes represent life also speaks about the symbolical nature of the new global power and inevitable symbolical collisions in the globalized world and make decisions, including political decisions. In this sense the power when it is real, becomes non-material ... Cultural battles an essence of fight for the power during information era. The power - as an opportunity to order behavior - contains in networks of information exchange and manipulation with symbols which correlate social actors, institutes and the cultural movements by means of pictograms, representatives, intelligent amplifiers" (Castells, 2000).

According to O.A. Karmadonov analyzing globalization processes including from positions of the dichotomy entered by him "a simbolizating - symbolization", - "if the history really is process of implementation of the idea of freedom (Hegel), it at the same time is, actually, and implementation process of "the idea of the power" And freedom more and more is freedom of the creative act, spiritual liberation of the individual, spontaneous and not limited simbolcreativity, the power, in turn, is characterized and measured by degree of a possibility of "address" to a certain symbolical system and deduction in it. Thereby freedom is a simbolizating, the power to eat symbolization expression. The global power is global symbolization" (Karmadonov, 2005).

Such famous French philosopher as Jean Baudrillard when he says that for the global power, "same fundamentalist, conservative as religious orthodoxy, all other than it, singular forms are heresies also warns about the same threat, as a matter of fact. Therefore they are doomed or to return willy-nilly to the global device, or have to disappear. The West mission (or it is rather an Ex-West as it has no own values 
for a long time) is in that all means to subordinate other cultures to the injurious law of equivalence, equivalence. Culture which lost the values can only recoup on values of others. Even the wars, including in Afghanistan, besides political and economic strategy are aimed at neutralization of wildness and alignment of all territories. The purpose - to minimize rebellious space, to colonize, subordinate all wild zones, whether it be in geographical space or in mental space" (Baudrillard, 2003).

\section{Conclusion}

At the same time, it is characteristic in this regard that, judging by data of the last researches among our compatriots, the main identification characteristics develop at our citizens around phenomena of a primordialny order today, first of all - families and the nations. The effect of lack of "civilization identity" takes place, and it is represented to us more significant, than presence of identity racial and national - brutalizatied and hypertrophied.

\section{References}

Baudrillard, Z. (2003). Globalization violence. In Logos, (1), 27.

Berger, P. (2002). The Cultural Dynamics of Globalization, in Berger, P., Huntington, S. (eds.) Many Globalizations: Cultural Diversity in the Contemporary World. New York: Oxford University Press, p. 16.

Bourdieu, P. (1991). The Production and Reproduction of Legitimate Language. Language and Symbolic Power. Cambridge: Harvard University Press, p. 51.

Buber, M. (1995). I and You. - Two images of belief. M.: Republic, p. 31.

Castells, M. (2000). Information era: Economy, society and culture. M.: HSE publishing house, p. 502-503.

Cohen, A. (2000). The Symbolic Construction of Community. London: Routledge, p. 12.

Giddens, A. (2000). Runaway World: How Globalization is Reshaping Our Lives. New York: Routledge, 2000, p. 17.

Hunter, J.D., Yates, J. (2002). In the Vanguard of Globalization: The World of American Globalizers, in Berger, P., Huntington, S. (eds.) Many Globalizations: Cultural Diversity in the Contemporary World. New York: Oxford University Press, p. 337-338.

Karmadonov, O.A. (2005). Globalization and symbolical power. In Questions of Philosophy, (5), 52.

Llosa, M.V. (2001). The Culture of Liberty. In Foreign Policy. January-February, p. 32.

Mach, Z. (1993). Symbols, Conflict, and Identity: Essays in Political Anthropology. Albany: State University of New York Press, p. 81, 43.

Panarin, A.S. (2003). Postmodernizm and globalization: project of release of owners from social and national obligations. In Questions of philosophy, (6), 27, 21.

Schrader, X. (1998). Globalization, civilization and morals. In Magazine of sociology and social anthropology, (Vol. 1), 12.

World Culture Report (2000). Paris: UNESCO Publishing. 


\title{
Проблема социальной идентичности
}

в глобализирующемся мире

\author{
И.А. Кардонова, В.И. Куйбарь \\ Иркутский государственный университет \\ Россия, 664003, Иркутск, ул. Карла Маркса, 3
}

Статья посвящена проблеме соииальной идентичности в глобализирующемся мире. Характерно, что «угрозы» идентичности, с которыми сталкиваются в ходе глобализационных проиессов, представляются более реальными и очевидными, в то время как «выигрыши» остаются в большей степени умозрительными. Преимущества, которые несет с собой в плане идентификационных процессов глобализачия, обычно описываются в связи с феноменом свободы выбора такой идентичности. Категории очевидности, «очевидные» для «глобализаторов», выступают универсальным мерилом, с которым подходят к оценке всех сопутствуюших глобализации явлений и социальной практики вообще. Естественно, что такой подход должен встречать известное сопротивление - символическому насилию, осуществляемому на глобальном уровне, противостоят как символические барьеры на локальных уровнях, так и антиглобалистское движение, само приобретающее глобальный характер.

Ключевые слова: идентификаиия, глобализационные прочессы, символы.

Научная специальность: 24.00.00 - культурология. 